\title{
Eosinophilic Granuloma with Splendore-Hoeppli Material Caused by Toxigenic Corynebacterium ulcerans in a Heifer
}

\author{
Kenji MURAKAMI ${ }^{1)}$, Eiji HATA $^{2)}$, Shinichi HATAMA ${ }^{2)}$, Yoshihiro WADA ${ }^{3)}$, Mitsuru ITO4), Yoshiharu ISHIKAWA ${ }^{2)}$ and \\ Koichi KADOTA ${ }^{2) *}$ \\ 1)Naka-Sorachi Agricultural Mutual Aid Association, 1-5-14 Omachi, Takikawa 073-0022, Japan \\ 2) Hokkaido Research Station, National Institute of Animal Health, 4 Hitsujigaoka, Toyohira, Sapporo 062-0045, Japan \\ 3) Ishikari Livestock Hygiene Service Center, 3 Hitsujigaoka, Toyohira, Sapporo 062-0045, Japan \\ 4) Tokachi Livestock Hygiene Service Center, 59-6 Kisen, Kawanishi, Obihiro 089-1182, Japan
}

(Received 20 November 2013/Accepted 2 March 2014/Published online in J-STAGE 17 March 2014)

ABSTRACT. Raised lesions were present on the left nasal vestibule of a 20-month-old Japanese Brown heifer. The largest mass which caused partial nasal obstruction was removed surgically. Corynebacterium ulcerans was identified in the mass. 16S ribosomal RNA and RNA polymerase beta subunit genes were $100 \%$ and $98 \%$ identical to other C. ulcerans strains. Histologically, multiple foci of eosinophilic granuloma with Splendore-Hoeppli material were seen. Rod-shaped Gram-positive organisms were detected with metachromatic granules, producing diphtheria toxin with 5,30 and 48 amino acid differences to another C. ulcerans strain, C. diphtheriae or C. pseudotuberculosis, respectively. The toxin is highly cytotoxic and may be responsible for the formation of abundant Splendore-Hoeppli material. The lesion was therefore judged to be an allergic reaction to bacterial antigens or diphtheria toxin.

KEY WORDS: cattle, Corynebacterium ulcerans, diphtheria toxin, eosinophilic granuloma, sulfur granule.

doi: 10.1292/jvms.13-0582; J. Vet. Med. Sci. 76(6): 931-935, 2014

Sulfur granules, which are usually located within neutrophil abscesses, are distinct masses of bacterial cells bordered by intensely eosinophilic, club-like projections of Splendore-Hoeppli material. This material is also formed around fungi, parasites and non-infectious agents and is encircled by eosinophils in cases, such as pythiosis and schistosomiasis [4]. In cattle, Splendore-Hoeppli phenomenon has been observed in some bacterial infections, including Actinomyces bovis and Actinobacillus lignieresii [9].

Bovine nocardiosis is usually accompanied by neutrophil accumulations, but in a case of eosinophilic granuloma, Nocardia-like organisms in the cytoplasm of multinuclear epithelioid cells have been reported [18]. Corynebacterium ulcerans is known as a pathogen that causes purulent inflammation, such as mastitis, lymphadenitis and respiratory infections, in various animal species [17]. However, necrotizing angitis with marked eosinophil infiltration associated with C. ulcerans has been reported in the human lung [13]. Toxigenic strains of $C$. ulcerans can induce pharyngeal infections mimicking classical diphtheria in humans [6]. The production of diphtheria toxin depends on infection by an organism with a corynephage-encoding diphtheria toxin gene [17]. Here, we report a case of nasal eosinophilic granuloma in a heifer, the lesion being characterized by Splendore-Hoeppli material containing toxigenic $C$. ulcerans.

*Correspondence to: Kadota, K., Hokkaido Research Station, National Institute of Animal Health, 4 Hitsujigaoka, Toyohira, Sapporo 062-0045, Japan. e-mail: kkadota@affrc.go.jp

(C)2014 The Japanese Society of Veterinary Science

This is an open-access article distributed under the terms of the Creative Commons Attribution Non-Commercial No Derivatives (by-nc-nd) License $<$ http://creativecommons.org/licenses/by-nc-nd/3.0/>.
A 14-month-old, Japanese Brown heifer was examined, because of a raised mass on the left nasal vestibule. A number of smaller nodules, frequently fused together, showed an irregularly elevated mucosal surface throughout. Despite antibiotic treatment, the lesion did not improve, and small elevations appeared on the right vestibule five months later. The largest mass causing partial nasal obstruction was resected surgically, six months after the initial examination. The mass, $4 \times 3 \times 1.5 \mathrm{~cm}$ in size, was relatively hard in consistency, and yellowish white nodules up to $5 \mathrm{~mm}$ in diameter were detected on cut sections. The heifer calved six weeks after surgery, and the mucosal condition of both vestibules was unchanged.

Most of the removed tissue was fixed in $10 \%$ buffered formalin, embedded in paraffin, sectioned at $4 \mu \mathrm{m}$ and stained with hematoxylin and eosin (HE), Gram, toluidine blue, Giemsa, phosphotungstic acid hematoxylin (PTAH), von Kossa and calcium stain (Dahl's method). Immunohistochemistry was carried out by the streptavidin-biotin complex/horseradish peroxidase (SAB) method on histological sections using a Histofine SAB kit (Nichirei, Tokyo, Japan). The primary antibodies employed were mouse monoclonal antibodies to CD68 (1:50; Dako A/S, Glostrup, Denmark) and tryptase (1:200; Lab Vision, Fremont, CA, U.S.A.), rabbit polyclonal antibodies to immunoglobulin $\mathrm{M}$ (IgM) ( $\mu$ chain specific) (1:1,600; Bethyl Laboratories, Montgomery, TX, U.S.A.) and $\operatorname{IgA}$ ( $\alpha$ chain specific) (1:1,600; Bethyl Laboratories) and a sheep polyclonal antibody to $\operatorname{IgG}(\gamma$ chain specific) (1:1,600; Bethyl Laboratories). Immunostaining was also performed using a biotin-conjugated goat polyclonal antibody to diphtheria toxoid (1:640; Thermo Fisher Scientific, Rockford, IL, U.S.A.) as part of the SAB kit. Some stainings were also performed on bacterial smears. For comparison, 


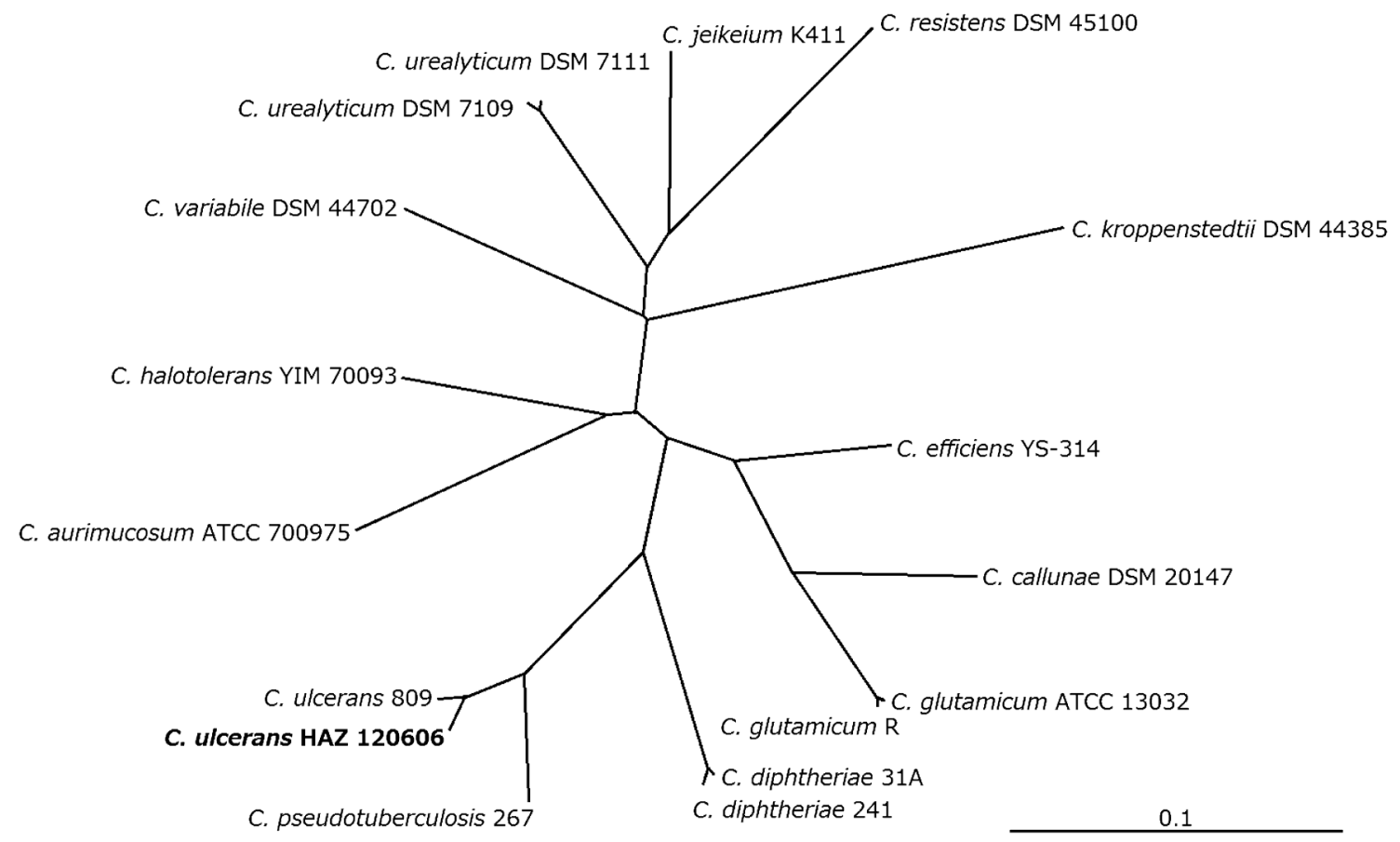

Fig. 1. Phylogenetic tree for different Corynebacterium species and C. ulcerans HAZ 120606 isolated from bovine eosinophilic granuloma, based on alignment of $r p o B$ sequences.

tissues from a case of actinomycosis and a case of actinobacillosis were treated in the same manner.

In order to identify bacterial organisms observed in tissue sections, part of the removed tissue that had been frozen for viral examination was utilized for culture. Its emulsion was cultured on $5 \%$ sheep blood agar at $37^{\circ} \mathrm{C}$ for one week aerobically or anaerobically. The dominant organisms were identified as a Corynebacterium, confirmed as Gram-positive, metachromatic granule-positive, hemolysis-positive, catalase-positive, nonspore-forming, nonmotile and rod-shaped. Sequencing of the $16 \mathrm{~S}$ ribosomal RNA gene (16Srrna), as previously mentioned for bacterial species identification [3], revealed similarities to other bacterial DNA sequences by BLAST (www.ncbi.nlm.nih.gov/blast). Although entirely corresponding to C. ulcerans strain 809 and sharing $>99.7 \%$ identity with other C. ulcerans strains, the 16Srrna of this isolate also possessed a very high degree of identity with a C. pseudotuberculosis strain. We then sequenced the RNA polymerase beta subunit-encoding gene $(r p o B)$ for definitive identification and compared it with other Corynebacterium species [7]. A phylogenetic tree of $r p o B$ was generated using the CLASTAL W program on the DNA Data Bank of Japan (www.ddbj.nig.ac.jp/) (Fig. 1). The rpoB of the isolate, which showed $98 \%$ identity with $C$. ulcerans strains, was registered with the Bank as an accession No. AB828262.

Histologically, in the propria-submucosa of the vestibule, there were multiple foci of granuloma, many of which contained eosinophilic hyaline deposits called the SplendoreHoeppli phenomenon (Fig. 2A). Most deposits were located within eosinophil abscesses surrounded by CD68-positive epithelioid cells and macrophages (Fig. 2B), but some were in direct contact with epithelioid cells. Abscesses localized within glandular ducts were rarely seen. Splendore-Hoeppli material was frequently calcified and/or infiltrated by eosinophils, and epithelioid cells phagocytosing calcified material were also seen. The material stained blue with PTAH and was partially positive for $\operatorname{IgG}, \operatorname{IgM}$ and $\operatorname{IgA}$. In addition to lymphocytes and plasma cells, tryptase-positive mast cells predominated in surrounding connective tissues.

In a few deposits of Splendore-Hoeppli material, rodshaped bacteria were relatively abundant and extended to the neighboring abscesses (Fig. 2C), but they were small in number in other deposits (Fig. 2D). The bacterial organisms were Gram-positive (Fig. 2D), having metachromatic granules at the ends of the cells (Fig. 2E). Immunohistochemistry demonstrated the presence of diphtheria toxin in the deposits (Fig. 2F) and showed its widespread distribution in some deposits. Immunoreactive products were also observed in accumulations of eosinophils.

Lesions were characterized by large bacterial colonies with peripheral club-like spicules in the two control cases (Fig. 2G). Surrounding infiltrates consisted of neutrophils, CD68-positive cells, lymphocytes and plasma cells, but few tryptase-positive cells. There were no calcium deposits in the spicules. Splendore-Hoeppli material stained blue with PTAH stain for fibrin. Immunohistochemical stains for IgG, $\operatorname{IgM}$ and $\operatorname{IgA}$ were positive within the Splendore-Hoeppli material in the case of actinomycosis, but were negative in the case of actinobacillosis.

Since nearly all organisms were variably positive for diph- 

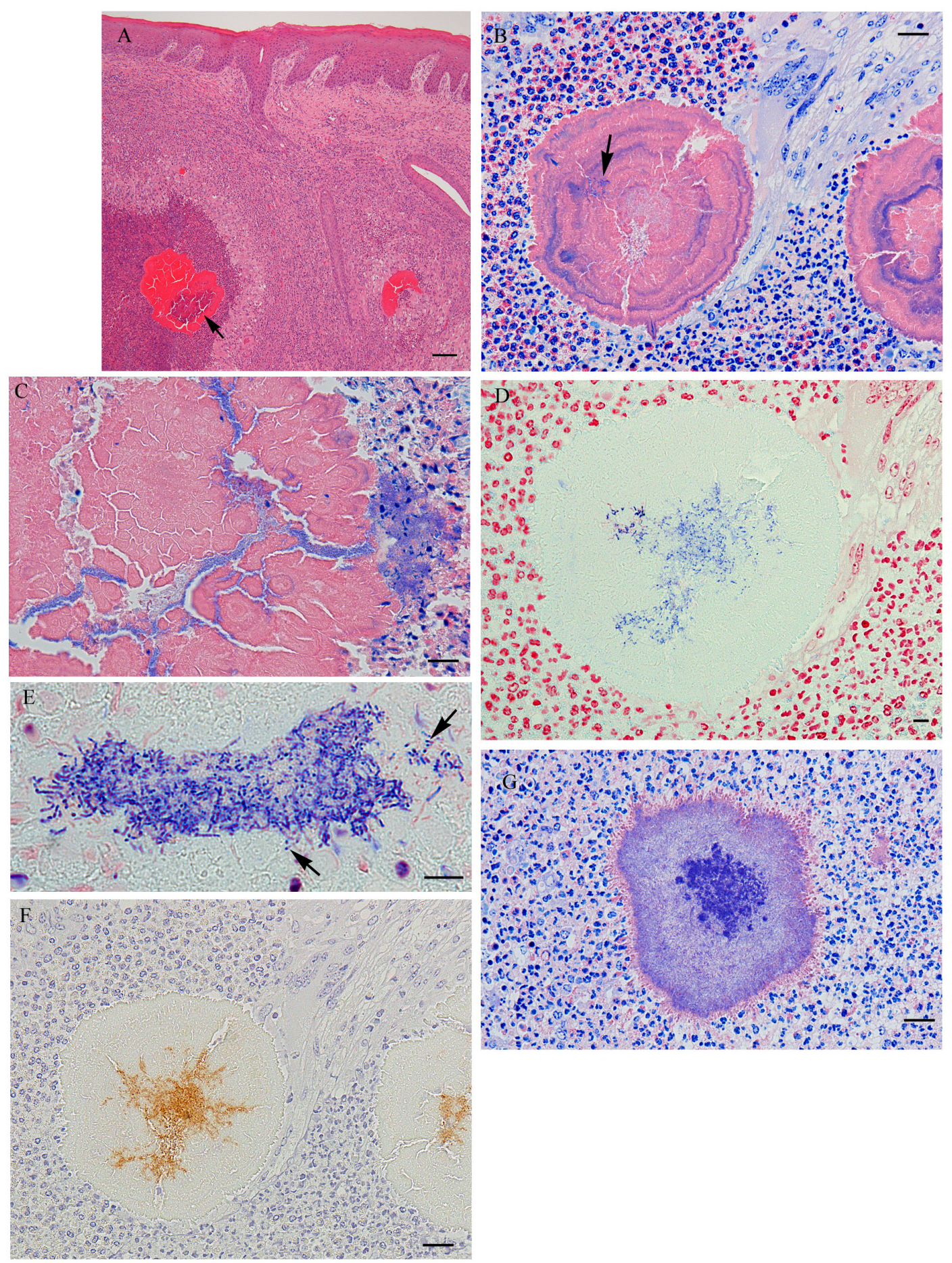

Fig. 2. Histology and immunohistochemistry of granulation tissues. (A) A large sulfur granule with eosinophil infiltration (arrow) is observed within an abscess. The other granule is surrounded by epithelioid cells (lower right). HE. Bar=100 $\mu \mathrm{m}$. (B) Intact bacterial organisms are small in number (arrow) or absent in sulfur granules encircled by eosinophils and epithelioid cells. Giemsa. Bar=20 $\mu \mathrm{m}$. (C) Many bacteria appear to be located between cracks of Splendore-Hoeppli material. Giemsa. Bar=20 $\mu \mathrm{m}$. (D) As shown in B, intact bacterial organisms are scarcely present, but Gram stain shows the existence of larger numbers of bacteria in the same sulfur granule. Gram. Bar=5 $\mu \mathrm{m}$. (E) Rod-shaped bacteria with metachromatic granules (arrows) are present within Splendore-Hoeppli material. Gram. Bar $=5 \mu \mathrm{m}$. (F) Staining for diphtheria toxin in a section adjacent to that depicted in D shows its localization in areas where bacterial organisms are visible. SAB, diaminobenzidine (DAB) chromogen, hematoxylin counterstain. Bar $=20 \mu \mathrm{m}$. (G) This actinomycotic sulfur granule is characterized by a large cluster of densely packed filamentous bacteria with a peripheral narrow band of eosinophilic club-shaped spicules. Unlike in B, infiltrating cells are neutrophils. Giemsa. Bar=20 $\mu \mathrm{m}$. 
theria toxin on bacterial smears by immunostaining, molecular analysis of the diphteria toxin gene was performed. Primers were designed from the C. ulcerans strain 0102 genome information (DTX-F: 5'-CTTGACCACGTTTTCCAC-3', DTX-R: 5'-CGATACTTCCTGGTATCG-3'). A diphtheria toxin gene was detected in the C. ulcerans isolate (accession No. AB828261). This toxin was different from that of another $C$. ulcerans strain, from $C$. diphtheriae strains and from a C. pseudotuberculosis strain by 5, 30 and 48 amino acids, respectively.

The most characteristic feature of the current case was the presence of Splendore-Hoeppli material surrounded by eosinophils, and histological examination revealed Grampositive organisms within the material or rarely eosinophil abscesses. Splendore-Hoeppli phenomenon is associated with several bacteria, such as Actinomyces, Streptomyces, Nocardia, Arcanobacterium, Staphylococcus, Streptococcus, Pseudomonas and Actinobacillus species [9-11, 15]. The present organisms were readily distinguishable from most of the species based on the Gram reaction and morphology including the presence of metachromatic granules. Additionally, C. ulcerans was bacteriologically isolated, and diphtheria toxin was immunohistochemically demonstrated in both tissue sections and bacterial smears [8]. On the basis of these results, toxigenic $C$. ulcerans was considered to be the causal agent of the eosinophilic granuloma.

Unlike in ordinary aspergillosis with neutrophil infiltration, eosinophils and epithelioid cells are observed in allergic bronchopulmonary aspergillosis in humans [2]. Similarly, not only neutrophil abscesses but also eosinophilic granuloma may occur in bovine nocardiosis [18]. The fungi and bacteria, which are respectively found within allergic mucin and epithelioid cells, are relatively small in number $[2,18]$. This may be due to the fact that they act as allergens. In the current case, bacterial organisms were also inconspicuous, and hence, the Splendore-Hoeppli phenomenon was much more prominent, compared with what is seen in other bacterial infections. Strains of C. ulcerans that produce diphtheria toxin are capable of forming pseudomembranes composed mainly of cell debris and fibrin on the mucosa of the human throat [16]. The Splendore-Hoeppli material is composed of tissue debris, fibrin and immunoglobulin [4, 5], and we demonstrated the presence of fibrin and immunoglobulins in the material. The intense cytotoxic effect of diphtheria toxin may be associated with the formation of abundant Splendore-Hoeppli material.

In sulfur granules, club-like peripheral projections of Splendore-Hoeppli material were thought to consist of calcium phosphate $[14,19]$. As shown in the control cases, however, the material is usually negative for von Kossa and calcium stain [4]. Although sulfur granules are usually embedded in neutrophil abscesses [9-11], the SplendoreHoeppli material formed around non-bacterial agents is frequently associated with eosinophils [4]. These cases provide evidence that neutrophils are not indispensable for the formation of sulfur granules.

The formation of the peribacterial Splendore-Hoeppli reaction probably prevents phagocytosis and intracellular kill- ing of the aggravating agent, leading to chronicity of infection [4]. In the present case, sulfur granules were infiltrated by eosinophils capable of releasing highly toxic granule proteins, free radicals and profibrinolysin $[1,12]$. Moreover, calcified sulfur granules were phagocytosed by epithelioid cells. Such mechanisms for eliminating Splendore-Hoeppli material and bacteria may result in loss of characteristic histological findings and difficulties in making a correct diagnosis in later stages of this type of granuloma.

\section{REFERENCES}

1. Barnhart, M. I. and Riddle, J. M. 1963. Cellular localization of profibrinolysin (plasminogen). Blood 21: 306-321. [Medline]

2. Bosken, C. H., Myers, J. L., Greenberger, P. A. and Katzenstein, A. L. 1988. Pathologic features of allergic bronchopulmonary aspergillosis. Am. J. Surg. Pathol. 12: 216-222. [Medline] [CrossRef]

3. Dorsch, M. and Stackebrandt, E. 1992. Some modifications in the procedure of direct sequencing of PCR amplified 16S rDNA. J. Microbiol. Methods 16: 271-279. [CrossRef]

4. Hussein, M. R. 2008. Mucocutaneous Splendore-Hoeppli phenomenon. J. Cutan. Pathol. 35: 979-988. [Medline] [CrossRef]

5. Johnson, M. M. 2010. Ear, nose, and throat infections. pp. 99-123. In: Diagnostic Pathology of Infectious Disease (Kradin, R. L. ed.), Saunders, Philadelphia.

6. Katsukawa, C., Kawahara, R., Inoue, K., Ishii, A., Yamagishi, H., Kida, K., Nishino, S., Nagahama, S., Komiya, T., Iwaki, M. and Takahashi, M. 2009. Toxigenic Corynebacterium ulcerans isolated from the domestic dog for the first time in Japan. Jpn. J. Infect. Dis. 62: 171-172. [Medline]

7. Khamis, A., Raoult, D. and La Scola, B. 2004. rpoB gene sequencing for identification of Corynebacterium species. J. Clin. Microbiol. 42: 3925-3931. [Medline] [CrossRef]

8. Komiya, T., Seto, Y., De Zoysa, A., Iwaki, M., Hatanaka, A., Tsunoda, A., Arakawa, Y., Kozaki, S. and Takahashi, M. 2010. Two Japanese Corynebacterium ulcerans isolates from the same hospital: ribotype, toxigenicity and serum antitoxin titre. J. Med. Microbiol. 59: 1497-1504. [Medline] [CrossRef]

9. Kubo, M., Osada, M. and Konno, S. 1980. A histological and ultrastructural comparison of the sulfur granule of the actinomycosis and actinobacillosis. Natl. Inst. Anim. Health Q. (Tokyo) 20: 53-59. [Medline]

10. Kubo, M., Osada, M. and Konno, S. 1981. Morphology of sulfur granules produced by Pseudomonas aeruginosa in cows. Natl. Inst. Anim. Health Q. (Tokyo) 21: 26-31. [Medline]

11. Kubo, M., Osada, M. and Konno, S. 1982. Morphology of sulfur granules produced by Staphylococcus aureus and Corynebacterium pyogenes in cows. Natl. Inst. Anim. Health Q. (Tokyo) 22: 130-137. [Medline]

12. Murphy, K., Travers, P. and Walport, M. 2008. Allergy and hypersensitivity. pp. 555-598. In: Janeway's Immunobiology, 7th ed., Garland Science, New York.

13. Nureki, S., Miyazaki, E., Matsuno, O., Takenaka, R., Ando, M., Kumamoto, T., Nakano, T., Ohkusu, K. and Ezaki, T. 2007. Corynebacterium ulcerans infection of the lung mimicking the histology of Churg-Strauss syndrome. Chest 131: 1237-1239. [Medline] [CrossRef]

14. Pine, L. and Overman, J. R. 1963. Determination of the structure and composition of the 'sulphur granules' of Actinomyces bovis. J. Gen. Microbiol. 32: 209-223. [Medline] [CrossRef]

15. Rodloff, A. C., Hillier, S. L. and Moncla, B. J. 1999. Peptostrep- 
tococcus, Propionibacterium, Lactobacillus, Actinomyces, and other non-spore-forming anaerobic gram-positive bacteria. pp. 672-689. In: Manual of Clinical Microbiology (Murray P. R., Baron, E. J., Pfaller, M. A., Tenover, F. C. and Yolken, R. H. eds.), 7th ed., ASM Press, Washington, D. C.

16. Schwartz, D. A. and Wharton, M. 1998. Diphtheria. pp. 145166. In: Pathology of Emerging Infections 2 (Nelson, A. M. and Horsburgh, C. R. Jr. eds.), ASM press, Washington, D. C.

17. Seto, Y., Komiya, T., Iwaki, M., Kohda, T., Takahashi, M. and Kozaki, S. 2008. Properties of corynephage attachment site and molecular epidemiology of Corynebacterium ulcerans isolated from humans and animals in Japan. Jpn. J. Infect. Dis. 61: 116-122. [Medline]

18. Shibahara, T., Mitarai, Y., Ishikawa, Y., Sato, M. and Kadota, K. 2001. Bovine nasal eosinophilic granuloma with blood eosinophilia caused by Nocardia species. Aust. Vet. J. 79: 363-365. [Medline] [CrossRef]

19. Smith, G. W. 2010. Actinobacillosis. pp. 539-540. In: Merck Veterinary Manual (Kahn, C. M. ed.), 10th ed., Merck, Whitehouse Station. 